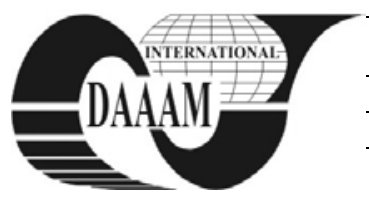

Annals of DAAAM for 2011 \& Proceedings of the 22nd International DAAAM Symposium, Volume 22, No. 1, ISSN 1726-9679 ISBN 978-3-901509-83-4, Editor B. Katalinic, Published by DAAAM International, Vienna, Austria, EU, 2011 Make Harmony between Technology and Nature, and Your Mind will Fly Free as a Bird Annals \& Proceedings of DAAAM International 2011

\title{
REFLECTIONS ON RESEARCH IN CORPORATE CAPITAL MANAGEMENT
}

\author{
TUDOSE, M[ihaela] B[rindusa]
}

\begin{abstract}
The study aims to provide a survey of existing literature on corporate capital management, to highlight particular research design approaches and to capture trends in order to drive research towards new potential ideas. The current body of research, while providing key analytical frameworks for grounding, understanding and implementing the firm's capital structure policy, has not yet produced a generally applicable definition.

Key words: capital structure, trade-off theory, pecking order theory, agency theory, market timing theory
\end{abstract}

\section{INTRODUCTION}

Research in capital management has constantly focused on developing optimal management rules that govern how firms determine the mix of equity and debt required to finance their investments. Compared with the earliest debates in the field, which revolved mainly around the capital structure irrelevance principle, the literature in the field vastly expanded subsequently, with in-depth examinations of issues such as: capital structure and value of the firm; capital structure and corporate governance; adjustments in capital structure during crisis; sustainability of financing sources. The main objective of this study is to highlight the particular aspects of various research focusing on corporate capital structure. The specific objectives are to capture evolving elements, determine the motives which prompt research development, showcase the particular aspects in the development of a financial theory and identify trends in research.

\section{THE CURRENT STATE OF RESEARCH}

Taking as temporal reference the period 1958-2011, it is readily apparent that the literature in the field has experienced tremendous development. F. Modigliani and M. Miller pioneered investigations into the firm's capital structure. They formulated two statements with major impact on subsequent research: "the market value of a firm is independent of its capital structure" and "a firm's leverage has no effect on its weighted average cost of capital” (Modigliani \& Miller, 1958). Although the validity of these statements was verified only in the context of predefined assumptions, describing an ideal situation, the two ideas represented the "starting point in laying the foundations of modern finance" (Stancu, 2007). Acknowledging the existence of common undercurrents and further considering the impact of various influencing factors, research in the area has been classified as follows: trade-off theory; pecking-order theory; agency theory; the firm's capital structure and factor-product markets and market timing theory.

\section{MILESTONES OF RESEARCH}

Trade-off theory emerged following criticism of Modigliani and Miller's theorem (Kraus \& Litzenberger, 1973). The new variables introduced in research were: corporate income tax, interest deductions and costs of financial distress, including bankruptcy costs. The novelty of the approach consisted in emphasising the role of the tax shields arising from debt financing. Continuing the research along the lines of maximising the value of the firm by increasing financing based on borrowed funds, the theory proposed two models for achieving the firm's target debt ratio: static trade-off (during which a firm operates under the assumptions of the trade-off theory for a definite period of time, e.g. one year); dynamic trade-off (which allows successive adjustment steps to reach the target debt ratio). In its ultimate form, trade-off theory postulates that a firm will borrow up to the point where the marginal value of tax shields on its borrowing is balanced by the increase in the present value of bankruptcy costs.

The pecking-order theory (Myers \& Majluf, 1984) asserts the priority of the order of financing sources over than their weight. Firms' preference for internal financing, followed by debt financing and equity issuance as a last resort, represents the pecking order of financing decisions under asymmetric information conditions. The novelty of the theory lies in incorporating information asymmetry, arguing that managers rather than outside investors have preferential access to information regarding the state of the firm. In recent years, a new pecking-order theory has emerged, focusing on developed economies, which readjusts the order of financing preference: retained earnings, equity capital and lastly, long-term debt (Delcoure, 2007).

Agent theory (Jensen \& Meckling, 1976). The new vision underlying the research argues that there is an agency relationship between shareholders and managers; thus, managers - serving as shareholders' agents - are required to act in the shareholders' best interests. However, the managers' and shareholders' interests may not always converge. Accordingly, managers may focus on a range of personal. Recent research has shown that although shareholders may deter such value transfers, the absolute monitoring of managements remains an unattainable ideal.

The theory linking the firm's capital structure and factorproduct markets incorporated new dimensions in the research: the role of non-financial stakeholders in designing the corporate finance structure, industrial organisation and the firms' strategic management. Research postulated the following principles: the existence of mutual influences between production factors and corporate financial decisions; links between financial structure and the degree of industrial concentration and between the financial structure and competition policy (Istaitieh \& Rodriguez-Fernandez, 2006).

Market timing theory has developed more recently and refers to companies' practice of issuing shares at a high price and repurchasing them at lower prices. The development of the theory rests on the premise that managers base their financing decision on capital market conditions. In unfavourable conditions, managers may consider postponing investment decisions. Consequently, corporate capital structure appears as the aggregate of managers' efforts to synchronise with the capital market. 


\section{REFLECTIONS}

The issues surrounding corporate financing have been and remain a major challenge. The motives which prompted research in the field have been extremely diverse, focusing variously on: the assumptions underlying the formulation of specific theories; the variables used to conduct research; the reliability and viability of previously proposed ideas; transformations in global society; the expansion of interdisciplinary research, etc.

As regards their architecture, each theory was based on a more or less realistic set of assumptions; in numerical terms, there have been intentions to curb restrictive assumptions (so as to be closer to reality) and to further diversify them (in order to better outline the context of the emergence of the respective theory). Each theory has developed based on a set of specific variables (which have become increasingly diverse over time). Examining retrospectively the emergence of the theories, the following set of variables comes into play: leverage, cost of capital, corporate income tax, interest deductions, cost of financial distress, information asymmetry and associated costs, agency relationships and related costs incurred, corporate strategy, market timing, etc. The incorporation in the analysis of an increasingly greater number of variables was required by the need to transcend the firm's exclusive objectives and additionally focus on the interests of shareholders, managers, lenders, employees, competitors, and consumers; finally, new research has aimed to analyse the psychological and sociological behaviour of the aforementioned stakeholders.

Another driver of research in the field was the refutation of previously formulated ideas; for example, trade-off theory emerged as a result of criticism levelled at Modigliani and Miller's models; pecking order theory itself was proposed as an alternative to the trade-off theory; and agency theory took shape on the assumption that the prior theories were unreliable theoretically and impossible to test empirically; and so on.

By stressing or, on the contrary, downplaying the importance of debt capital, the various theories have taken different stands with reference to the potential existence of an optimal capital structure. Static trade off theory defines optimal capital structure as a balance between the tax shield benefits derived from debt and the costs of financial distress. Conversely, pecking order theory suggests that no optimal capital structure exists. Agency theory posits that optimal capital structure may result from minimising the costs generated by the conflicts of interest between the firm's stakeholders. Market timing theory does not embrace the idea of the existence of a target capital structure.

Lately, research has oriented towards exploring the implications of macroeconomic conditions on selecting the financing mix. For example, the current crises have determined a reassessment of risks entailed by the various forms of financing. Moreover, in addition to sustainable development concerns (as a background issue), an operational problem emerges: financing sustainable economic activity. Thus, in financial matters, the focus has shifted from optimality in favour of sustainability concerns. Analyses have dealt both with the sustainability of financing sources and with designing a sustainable financing portfolio (Dinga, 2009).

In examining the dynamics of corporate finance research, financial theories emphasise that its sphere has expanded constantly, as it engages in interdisciplinary analyses. Such approaches have led to the integration of finance in strategic management, in marketing, in human resource management, etc. We are witnessing in fact a dismantling of subject boundaries in economic research.

In terms of the particular aspects involved in designing the theories under review, it is apparent that most theories developed analytical frameworks, vital for building, explaining and implementing the firm's financing policy. The specific elements of each research depend on how it dealt with and incorporated the following stages: formulating the assumptions, modelling and empirical verification and testing in different environments.

Considering that research in the field has expanded considerably over the years, we would like to note that, for the purposes of this study, we aimed to provide a selection of the most relevant research; hence, we acknowledge that the study does not claim to be exhaustive. Furthermore, we recognise that due to the rather sterile overview of theories (focusing mainly on their founders) we may attract blame for improper scientific grounding; the real reason is different however - i.e. lack of space. Beyond these limitations, we consider that the stated opinions remain relevant.

\section{CONCLUSIONS}

The development of theories of corporate financing bears the imprint of the dominant trend in contemporary science - the design of new theories that overturn tradition (making the transition from the classical theory of capital structure irrelevance to the relevance of capital structure). We are witnessing a tumultuous (r)evolution in the field of financial theories, as new research undertakings question the reliability of previously formulated theories and incorporate increasingly more variables, as they seek to account for a highly complex reality and also to stake out a key position in ongoing debates. Research in the field has thus oriented towards new directions or has taken paths less travelled. The paper serves as a starting point for conducting future, more extensive research within the framework of the training program for elite researchers.

\section{ACKNOWLEDGEMENTS}

This work was supported by the project "Post-Doctoral Studies in Economics: training program for elite researchers SPODE" co-funded from the European Social Fund through the Development of Human Resources Operational Programme 2007-2013, contract no. POSDRU/89/1.5/S/61755.

\section{REFERENCES}

Delcoure, N. (2007). The determinants of capital structure in transitional economies. International Review of Economics and Finance, vol. 16, Issue 3 (Jan. 2007), pp. 400-415, ISSN 1059-0560

Dinga, E. (2009). Studii de economie, Editura Economica, ISBN 978-973-709-488-9, Bucuresti

Istaitieh, A., Rodriguez-Fernandez, J. M. (2006). Factorproducts market and firm's capital structure: a literature review. Review of Financial Economics, vol. 15, (Feb. 2006), pp. 49-75, ISSN 1058-3300

Jensen, M., Meckling, W. (1976). Theory of the firm: managerial behavior, agency cost and capital structure. Journal of Financial Economics, vol. 3, Issue 4, (Oct. 1976), pp. 305-360, ISSN 0304405X

Kraus, A., Litzenberger, R.H. (1973). A state preference model of optimal financial leverage. Journal of Finance, vol. 28, Issue 4 (Sep. 1973), pp. 911-922, ISSN 1540-6261

Modigliani, F., Miller, M. (1958). The cost of capital, corporation finance and theory of investment. American Economic Review, vol. 48 (Jun., 1958), pp. 261-297, ISSN 0002-8282

Myers, S., Majluf, N. (1984). Corporate financing and investment decisions when firms have information that investors do not have. Journal of Financial Economics, vol. 13, (Jun. 1984), pp. 187-221, ISSN 0304405X

Stancu, I. (2007). Finante, Editura Economica, ISBN 978-973709-320-2, Bucuresti 